\title{
[Rec.:] „Rocznik Muzeum Wsi Mazowieckiej w Sierpcu”, Tom X, 2019, ss. 122
}

W 2011 r. ukazał się pierwszy tom „Rocznika Muzeum Wsi Mazowieckiej w Sierpcu”. Równolegle placówka zintensyfikowała działalność naukowo-popularyzatorską, organizując z podziwu godną regularnością coroczne konferencje muzeologiczne o charakterze ogólnopolskim i międzynarodowym. Tym samym Muzeum Wsi Mazowieckiej (MWM) dało się poznać jako prężny ośrodek nie tylko praktyki, ale i teorii skansenowskiej, goszcząc ekspertów z ośrodków muzealnych oraz akademickich.

Periodyki muzealne stanowią szczególny rodzaj wydawnictw naukowych. W dobie ewaluacji czasopism, monografii i materiałów pokonferencyjnych dokonywanej przez rozmaite gremia, periodyki te są skazane na „gonienie” (pod względem procedur wydawniczych) tytułów firmowanych przez uczelnie wyższe i inne ośrodki badawcze. Jeśli nie wezmą udziału w tym wyścigu, nie przyciągną autorów-akademików, stając się tym samym platformą wymiany myśli w zamkniętym gronie muzealników. Stracą na tym oba wspomniane środowiska. Istnieje też niebezpieczeństwo, że w trybach automatyzmu parametryzacyjnego arbitralnie zanegowany zostanie naukowy charakter wielu wartościowych periodyków muzealnych, a pośrednio także naukowy charakter muzeum jako instytucji. Redaktorzy tych czasopism muszą zatem realizować wytyczne powstające poza ich macierzystym środowiskiem, ale - paradoksalnie - to na nich summa summarum spoczywa ciężar zachowania, jakże istotnych dla nauki, związ- 


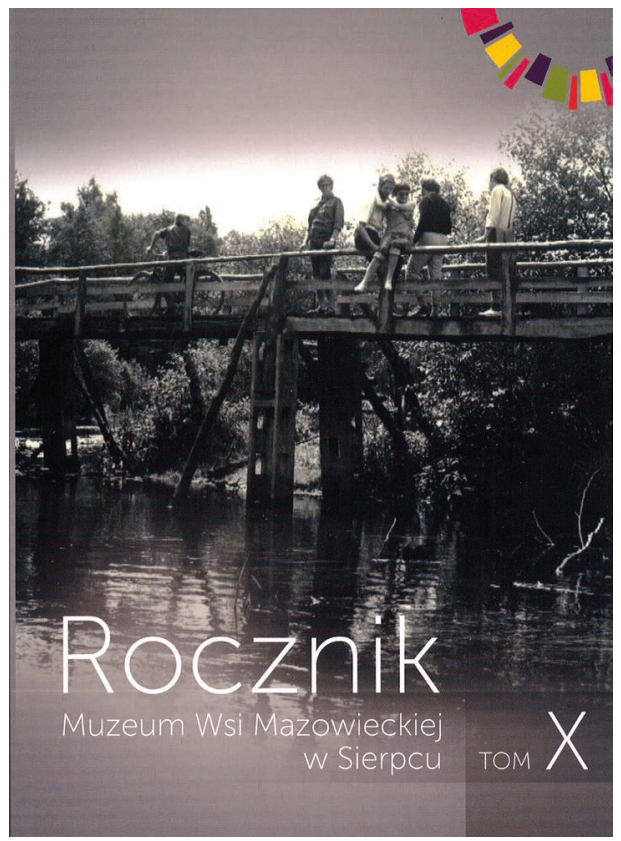

ków między muzeum i akademią [por. m.in. Barański 2014: 16-21; Lica-Kaczan 2014: 99-105; Piaskowski 2014: 142-144].

Jednym z tytułów konsekwentnie zasilających dyskurs muzeologiczny tekstami pisanymi z rozmaitych perspektyw jest „Rocznik Muzeum Wsi Mazowieckiej w Sierpcu”. Na zawartość X tomu składa się sześć artykułów i pięć tekstów wypełniających dział recenzji. Cztery pierwsze artykuły stanowią pokłosie zorganizowanej w listopadzie $2018 \mathrm{r}$. w MWM Ogólnopolskiej Konferencji Naukowej zatytułowanej Śmiech i powaga $w$ przestrzeni muzealnej.

Karolina Radłowska z Uniwersytetu w Białymstoku prezentuje tekst Publiczność muzealna jako „wspólnota śmiechu”. Społeczny odbiór Muzeum Bimbrownictwa. Sięgając po koncepcje Piotra Sztompki, Tomasza Goban-Klasa i Kazimierza Żygulskiego autorka poddaje teoretycznej analizie rodzaj wspólnoty jaką tworzą odbiorcy muzealni. Dochodzi przy tym do wniosku, że publiczność ta, w określonych okolicznościach, może tworzyć rodzaj więzi społeczno-kulturowej określanej mianem „wspólnoty śmiechu”. Egzemplifikacją tak nakreślonego układu jest według Radłowskiej publiczność odwiedzająca „Muzeum Bimbrownictwa”, czyli prezentację funkcjonującą w ramach Podlaskiego Muzeum Kultury Ludowej. Autorka kreśli genezę ekspozycji i skomplikowany (ze względu na kontekst) proces budowania znaczeń w ramach idei uzasadniającej powstanie takiego miejsca. Najistotniejszym elementem, z uwagi na problematykę sygnalizowaną w tytule artykułu, jest regularnie organizowana w podlaskiej placówce inscenizacja procesu wyrobu alkoholu za pomocą eksponowanej aparatury bimbrowniczej. Inscenizacja ta, posiadająca charakter performansu prowadzonego z udziałem aktora scen białostockich, staje się wehikułem budowania „wspólnoty śmiechu”. Zdaniem Radłowskiej, dzięki umiejętnie podsycanej interakcji oraz skojarzeniom jakie wywołuje bimbrownicza problematyka, goście muzealni reagują emocjonalnie, spontanicznie dzieląc się wspomnieniami, anegdotami i opowieściami. Ciekawym wątkiem 
rozwijanym przez autorkę staje się założenie, że podczas wspomnianej prezentacji wyłania się sprzeczność między tradycyjnie pojmowaną powagą przestrzeni muzealnej a naruszającym to dostojeństwo zjawiskiem bimbrownictwa. Efektem tego dychotomicznego napięcia jest komizm, odczytywany przez zwiedzających dzięki ich kompetencjom kulturowym. Ten ciekawy artykułu może być inspirujący dla autorów pragnących w przyszłości zajmować się podobną problematyką, choć szerzej zakrojone rozważania wymagałyby zapewne sięgnięcia po koncepcje klasyków teorii kultury zabawy tej miary co Johan Huizinga czy Roger Caillois oraz zwrócenia uwagi na rolę nostalgii i jej nieoczywistych, a przez to ciekawych, związków z komizmem i śmiechem. Nostalgia to specyficzna przestrzeń pamięci, w której czujemy się dobrze [Zaleski: 11-26].

Jeśli tekst otwierający X tom „Rocznika Muzeum Wsi Mazowieckiej w Sierpcu” jest efektem poszukiwania śmiechu na gruncie muzealnym, to drugi artykuł noszący tytuł Przypadek Radosława P. Refleksje o pracy muzealnika kieruje czytelnika w stronę muzealnej powagi. Jego autorka Magdalena Łuków vel Broniszewska z Muzeum Śląskiego w Katowicach próbuje, w duchu po trosze autoetnograficznym, zmierzyć się z zagadnieniem niezwykle doniosłym. Chodzi mianowicie o kwestię, czy muzealnik może (lub powinien) promować dzieła, wiedząc że ich autorem jest osoba odsiadująca wyrok dożywotniego więzienia, co jak wiemy jest konsekwencją popełnienia wyjątkowo ciężkiego przestępstwa, w praktyce — zbrodni. Dzieła takie uwikłane są bez wątpienia w specyficzny kontekst, zaś muzeum i jego pracownik (jako twórca kolekcji lub kurator wystawy) rozstrzygnąć muszą, czy firmować dzieło o ambiwalentnym statusie etycznym. Zaczynem dla refleksji stała się dla autorki wystawa przygotowana w $2017 \mathrm{r}$. przez Muzeum Śląskie w Katowicach, zatytułowana Nie jestem już psem. Wśród twórców, których prace zaprezentowano, znalazł się tytułowy Radosław P., którego malarstwo jest przykładem twórczości „art brut”. Łuków vel Broniszewska słusznie zauważa, że o ile obecność dzieł tego artysty w zbiorach jest uzasadniona, to pozostaje jednak nierozstrzygnięta kwestia sumienia muzealnika w świetle zachowań określanych jako pożądane dla przedstawicieli tego zawodu. Dochodzi tu do wyraźnego konfliktu. Muzealnik wykonuje zawód zaufania publicznego, któremu przypisuje się wyjątkowe standardy etyczne. Jednocześnie wytyczne dotyczące zachowań i postępowań, ujęte w dokumencie, jakim jest Kodeks Etyki dla Muzeów ICOM, wskazują na dobro muzeum jako wartość naczelną. Zatem: 
„wartości muzealnicze oraz indywidualne wartości każdego człowieka (związane z doświadczeniem, wychowaniem, wyznaniem etc.) należą do dwóch różnych systemów, do których człowiek się odnosi” (s. 24). Dalej autorka doprecyzowuje powstały dylemat: „pewność, jaką muzealnik może uzyskać odnośnie do wykonywanej pracy, może stać w opozycji wobec własnych przekonań” (s. 25). Kazus Radosława P. generuje szereg refleksji nad rolą muzeum jako miejsca, gdzie realizuje się cele naukowe, edukacyjne, opiniotwórcze, kreuje zdolność krytycznego myślenia, buduje postawę otwarcia na kulturę Innego. Tekst w sposób ciekawy i odważny prowokuje do zadumy nad etycznym wymiarem pracy muzealnika, jego kompetencjach, sposobach pojmowania prawdy, a także nad istotą zawodu zaufania publicznego. Łuków vel Broniszewska wskazuje, że nie wszystkie zapisy stworzonego w 1986 r. Kodeksu Etyki ICOM mają przełożenie praktyczne, a niektóre mogą być nawet wobec siebie sprzeczne.

Kolejny artykuł stanowi powrót do znacznie swobodniejszej, choć nie mniej istotnej problematyki. Patrycja Hajder jest autorką tekstu Bal w pałacu - o edukacji Muzeum Pałacu w Rogalinie, adresowanego przede wszystkim do muzealnych edukatorów oraz odbiorców przygotowanej przez nich oferty. Autorka - pracownik rogalińskiej placówki — dokonuje swoistego odkrycia. Otwarty w 2015 r. po wielu latach remontów Muzeum-Pałac jako Oddział Muzeum Narodowego w Poznaniu, stał się miejscem udanych działań edukacyjnych. Ich pomysłodawcami i realizatorami byli młodzi pracownicy nieposiadający większego doświadczenia w zakresie tego rodzaju działalności. Hajder dowodzi, że „intuicyjnie” opracowali oni propozycję lekcji muzealnej, podczas której uczniowie młodszych klas szkoły podstawowej przekonują się, że „taniec jest pewną syntezą, skupiającą różne przejawy kultury związane z konkretnym czasem w historii” (s. 33). Wykorzystywane podczas zajęć techniki — rozmowa sterowana oraz warsztat - zawierają cztery czynniki: zmianę pozycji słuchacza w pozycję badacza, element zabawy, aspekt emocjonalny, zapewnienie otoczenia bogatego w bodźce zmysłowe. Zdaniem autorki, wszystkie te czynniki sprawiają, że Bal w pałacu można zaliczyć do zajęć wychodzących naprzeciw postulatom neurodydaktyki, w ramach której tworzone są warunki do „nauki przyjaznej mózgowi”. W świetle tych rozważań mało zgrabny tytuł artykułu nabiera nowego znaczenia. Czy nie powinien on brzmieć: „...o edukacji w Muzeum...”? Kwestia z pozoru błaha stanowić może zaczyn poważniejszej refleksji. Pałac (jako siedziba muzeum) z ontologicznego 
punktu widzenia nie jest bytem, który może w sposób świadomy edukować. Trudno jednak zaprzeczyć, że zabytki posiadają same w sobie wartość edukacyjną i przy odpowiednim nastawieniu obserwatora mogą nas wiele nauczyć. Z jednej strony Hajder opisuje zaplanowaną przez edukatorów realizację (edukacja w muzeum), z drugiej zaś, to właśnie przestrzeń pałacowa tworzy kontekst dający nadzieję skutecznych działań (edukacja muzeum), co autorka słusznie uwzględnia.

Z kolei Zofia Gralak z Uniwersytetu Łódzkiego prezentuje artykuł zatytułowany Przeprowadzenie badań dotyczacych odbioru dzieł sztuki artystów pochodzacych z Afryki Wschodniej na wybranej grupie respondentów odwiedzających wystawę pt. „Między sztuka a opętaniem. Hebanowe bestiarium ludu Makonde. Fotografie Piotra Sadurskiego". Zgodnie z tytułem autorka streszcza projekt, przebieg i wyniki badań przeprowadzonych na 14-osobowej grupie osób, które odwiedziły wystawę przybliżającą twórczość rzeźbiarską Makonde - ludu z grupy Bantu, zamieszkującego pogranicze Tanzanii i Mozambiku. W ramach badań, które - jak stwierdza sama autorka - cechowały „minimalizm i prostota” (s. 49), pytano m.in. o: emocje jakie towarzyszyły zwiedzającym na skutek kontaktu z rzeźbą Makonde; wspomnienia, które ona generuje; wyobrażenia dotyczące sztuki afrykańskiej. Zachęcano także do prób odczytania intencji artystów, pytano też o przyczynę odwiedzin. Wywiady kierowane połączone z ankietą uzupełniała metoda polegająca na zaznaczeniu najmocniej oddziałujących na odbiorcę detali dziesięciu zaprezentowanych prac. Tekst jest zredagowany mało starannie. Świadczą o tym powtarzające się informacje, a nawet całe zdania, na stronach 42, 43 i 46. Można mieć także wątpliwości, czy konkluzja głosząca, że: „odbiór dzieł sztuki stanowi sprawę indywidualną, przynależną dla danej osoby” (s. 59) wnosi coś odkrywczego do teorii sztuki? Może się to wydawać dziwne, ale wygląda na to, że autorka, w wirze rozważań teoretyczno-metodologicznych, zapomniała też poinformować czytelnika, która z warszawskich bibliotek gościła wystawę. Wartość artykułu jest raczej pochodną egzotyki kultury Makonde (sporo dowiadujemy się na jej temat), zaś wyniki opisanych w tekście badań stanowić mogą przyczynek do rozważań na temat postaw odbiorców wobec sztuki afrykańskiej oraz funkcji, jakie pełni twórczość artystów tego kontynentu w kontekście europejskiego odbiorcy.

\footnotetext{
${ }^{1}$ Była to Biblioteka Publiczna m.st. Warszawy — Biblioteka Główna Województwa Mazowieckiego przy ul. Koszykowej 26/28.
} 
W tomie wyodrębniono dział ŚWIAT RZECZY składający się z dwóch artykułów. Paweł Marek Pogodziński z Muzeum Archeologicznego w Gdańsku i Uniwersytetu Gdańskiego w tekście Mazowiecki upcykling. Unikatowa architektura małomiasteczkowa $\mathrm{z}$ XIX iXX wieku z wykorzystaniem fragmentów statków wiślanych $w$ Czerwińsku nad Wisła analizuje fenomen mogący stanowić przedmiot zainteresowania zarówno etnografa, jak i archeologa. Czerwińsk, znany głównie za sprawą obecnego tu romańskiego kościoła pod wezwaniem Zwiastowania NMP, przyciąga uwagę autora z innego powodu. Część zachowanych obiektów drewnianej zabudowy tej miejscowości została bowiem wykonana przy użyciu elementów pochodzących z wyeksploatowanych statków wiślanych, tak zwanych berlinek, co Pogodziński trafnie nazywa swoistym upcyklingiem. Wprawdzie — jak zauważa — praktyka wykorzystywania drewna z jednostek pływających jako materiału budowlanego była znana na ziemiach polskich już od średniowiecza, jednak liczba zachowanych przykładów, pozwala określić Czerwińsk jako miejsce pod tym względem unikatowe. Zdrowe drewno wyeksploatowanych jednostek - głównie klepki poszycia - było wykorzystywane z dwóch podstawowych powodów. Pierwszym był brak materiału budowlanego na terenach wylesionych (Mazowsze Płockie do takich należało), drugim zaś, specyfika materiału z którego budowano berlinki - było to wyselekcjonowane, pozbawione sęków drewno dębowe i wysokiej jakości sosnowe, które nawet po latach eksploatacji na wodzie zachowywało część swoich cennych właściwości. Pogodziński słusznie wskazuje, że mamy tu do czynienia z elementem nadwiślańskiego dziedzictwa, potencjalną atrakcją uzupełniającą pejzaż kulturowy Czerwińska zdominowany romańską architekturą sakralną. Autor apeluje w związku z tym o konsekwentną dokumentację i ochronę konserwatorską tych szczególnych obiektów. To świetny artykuł, szkoda tylko, że zabrakło w nim informacji cennej dla niewtajemniczonego - czy i w jaki sposób można rozpoznać drewno szkutnicze w konstrukcji budynku?

Karolinę Echaust reprezentującą Muzeum Narodowe Rolnictwa i Przemysłu Rolno-Spożywczego w Szreniawie oraz Uniwersytet im. Adama Mickiewicza w Poznaniu zainteresowała Tradycja odlewania świec na kole $w$ Białej k. Płocka. Trzy dekady wcześniej Wanda Dowlaszewicz z Muzeum Mazowieckiego w Płocku sporządziła etnograficzny opis tej „żywej” praktyki [1991]. Prezentowany w „Roczniku” materiał można więc potraktować jako kontynuację obserwacji wówczas przeprowadzonej. Echaust lokuje działania 
brastewnych (mężczyzn - członków Bractwa Różańcowego, zajmujących się rokrocznie odlewaniem świec z wosku pszczelego na potrzeby kościoła i parafian) w nowym kontekście niematerialnego dziedzictwa kulturowego i procesów tożsamościowych. Ciekawy jest też sposób opisu, różny od tego, który zaproponowała onegdaj Dowlaszewicz. Echaust konstruuje narrację „na nową modłę” z wykorzystaniem fragmentów wywiadów (rozmów) z brastewnymi. To oczywiście pozwala uchwycić perspektywę badanego. Z drugiej zaś strony, Dowlaszewicz wymieniała z imienia i nazwiska ludzi, których obserwowała przy pracy. Współczesna narracja ukrywa ich pod inicjałami i numerami nadanymi wywiadom. To przyczynek do refleksji nad zmianami, którymi podlega etnograficzny tekst. Wartość materiału prezentowanego w sierpeckim wydawnictwie polega przede wszystkim na tym, że dokumentuje on fakt kontynuowania tradycji lania świec w Białej pod Płockiem. Czy za kolejne 30 lat znajdzie się badacz, który podobnie jak Dowlaszewicz i Echaust, opisze czytelnikom nadal „żywą” tradycję?

Całość tomu zamyka obszerny dział recenzji. Omówiono tu trzy wystawy i dwie pozycje książkowe. Izabela Radkowska przyjrzała się wystawie Macierzyństwo od początku i bez końca. Antropologiczna opowieść, którą można było obejrzeć w Muzeum Etnograficznym im. Marii Znamierowskiej-Prüfferowej w Toruniu, Bartłomiej Zaleśkiewicz zrecenzował wystawę Gniewne miasto. O konfliktach $w$ dawnym Toruniu zorganizowaną w $\mathrm{Mu}-$ zeum Historii Torunia, zaś Ewelina Wolska przybliżyła ekspozycję Świat toruńskiego piernika prezentowaną w Muzeum Toruńskiego Piernika Oddziale Muzeum Okręgowego w Toruniu. Książki zrecenzowali: Mateusz Napiórkowski, który podzielił się refleksjami po lekturze dzieła Zacka Davissona, Yurei. Niesamowite duchy w kulturze japońskiej w tłumaczeniu A. Czwojdraka, wydanej przez Uniwersytet Jagielloński, natomiast Sara Orzechowska przyjrzała się pozycji Lecha Ostasza, Filozofia prasłowiańska. Próba rekonstrukcji i uzupetnienia, Wyd. FDS, Olsztyn 2017. Ze względu na lokalizację omówionych tu wystaw oraz fakt, że wszyscy autorzy recenzji posiadają afiliację Uniwersytetu Mikołaja Kopernika, w dziale tym dominuje toruńskość. Z perspektywy dziesięciu tomów można powiedzieć, że to trwała cecha „Rocznika Muzeum Wsi Mazowieckiej”. Przyczyna wydaje się oczywista. Sierpecką placówkę łączą z Toruniem liczne i wieloletnie związki instytucjonalne i personalne. Z uwagi na owoce owej synergicznej współpracy, wypada życzyć wszystkim muzeom na wolnym powietrzu i każdemu uniwersytetowi podobnego partnerstwa. 


\section{Bibliografia}

\section{Barański Janusz}

2014: Polskie muzeum etnograficzne w XXI wieku, „Zbiór Wiadomości do Antropologii Muzealnej”, nr 1, s. 13-21.

\section{Dowlaszewicz Wanda}

1991: Żywa tradycja „lania świec” w Białej koło Płocka, „Rocznik Muzeum Mazowieckiego w Płocku”, nr 16, s. 82-91.

\section{Lica-Kaczan Magdalena}

2014: Polskie muzeum etnograficzne wXXI wieku. Ankieta czasopisma „Zbiór Wiadomości do Antropologii Muzealnej”, „Zbiór Wiadomości do Antropologii Muzealnej”, nr 1, s. 89-106.

\section{Piaskowski Grzegorz}

2014: Polskie muzeum etnograficzne w XXI wieku. Ankieta czasopisma „Zbiór Wiadomości do Antropologii Muzealnej”, „Zbiór Wiadomości do Antropologii Muzealnej”, nr 1, s. 127-145.

\section{Zaleski Marek}

2004: Formy pamięci, Gdańsk: słowo/obraz terytoria. 